\title{
OPEN First freshwater mussel-associated piscicolid leech from East Asia
}

\author{
Ivan N. Bolotov ${ }^{1,2}$, Anna L. Klass ${ }^{1,2}$, Ekaterina S. Konopleva ${ }^{1,2 \varpi}$, Yulia V. Bespalaya ${ }^{1,2}$, \\ MikhailYu. Gofarov ${ }^{1,2}$, Alexander V. Kondakov ${ }^{1,2}$ \& llya V. Vikhrev ${ }^{1,2}$ \\ Parasites and symbionts of freshwater mussels are poorly understood, although a diverse assemblage \\ of mussel-associated leeches (Glossiphoniidae) was recently described. Here, we report on the \\ discovery of a fish leech (Piscicolidae) in the mantle cavity of the freshwater mussel Cristaria plicata \\ (Unionidae) in the Russian Far East. It is the first member of this leech family being associated with \\ freshwater molluscs. This leech does not match any known genus and species both morphologically \\ and genetically, and is described here as Alexandrobdella makhrovi gen. \& sp. nov. It uses mussels as \\ shelter (and probably as a secondary host), while the Amur catfish Silurus asotus (Siluridae) seems to \\ be the primary host. These novel findings indicate that mussel-associated leech assemblage contains \\ at least one piscicolid species. Our fossil-calibrated phylogeny suggests that the crown group of \\ Piscicolidae was originated in the Early Cretaceous. This primarily marine family shares at least five \\ independent colonization events into freshwater environments.
}

Mussel-associated leeches are a species-rich ecological group, examples of which have been described from North America, Africa, India and Nepal, Southeast Asia, and East Asia ${ }^{1,2}$. It was shown that most of mussel-associated leeches use freshwater mussels (order Unionida) as secondary hosts and shelter, while various freshwater fish species serve as the primary host ${ }^{2}$. All mussel-associated leeches known to date belong to three genera in the family Glossiphoniidae, i.e., Batracobdelloides Oosthuizen, 1986, Hemiclepsis Vejdovsky, 1884, and Placobdella Blanchard, $1893^{2}$. Furthermore, several glossiphoniid leeches are associated with freshwater gastropods, with examples reported from Africa ${ }^{3}$, North America ${ }^{4}$, and Southeast Asia ${ }^{5}$. The freshwater leech Alboglossiphonia polypompholyx Oosthuizen, Hussein \& El-Shimy, 1988 from Egypt seems to be a unique example of an obligate parasite of the mantle cavity of freshwater snails ${ }^{3,6}$, although a number of taxa could be overlooked due to the hidden life style of such small leeches.

None of the fish leeches (Piscicolidae) was known to occur in association with freshwater mollusks, although the marine fish leech Pontobdella moorei (Oka, 1910) uses Octopus bimaculatus Verrill, 1883 (Cephalopoda: Octopodidae) as the primary host ${ }^{7}$. This leech family contains numerous marine taxa (including several species discovered from oceanic trenches up to $8.7 \mathrm{~km} \mathrm{deep}^{8}$ ) alongside with a few radiations in fresh water ${ }^{9-11}$. However, the origin of fresh- and brackish-water lineages of Piscicolidae is still unclear. Lukin ${ }^{12}$ and Epshtein ${ }^{13}$ hypothesized that freshwater piscicolid leeches originated from marine ancestors. Later, this hypothesis was corroborated based on molecular data obtained from mitochondrial DNA ${ }^{14}$. It is currently accepted that the family Piscicolidae contains three subfamilies: Piscicolinae Johnston, 1865, Platybdellinae Epshtein, 1970, and Pontobdellinae Llewellyn, $1966^{14,15}$. The first subfamily was recovered as non-monophyletic using a DNA-based approach $^{16}$. Recently, the family Piscicolidae together with the Ozobranchidae were placed in the separate suborder Oceanobdelliformes ${ }^{17}$.

This correspondence (1) reports on the first example of an association of a piscicolid leech species (Hirudinea: Piscicolidae) with freshwater mussels; (2) describes this leech as a genus and species new to science; (3) reconstructs a time-calibrated phylogeny of the piscicolid leeches, and (4) discusses the origin of freshwater lineages in this family in a broader evolutionary context.

\section{Results}

A sample of fish leeches collected from the mantle cavity of the freshwater mussel species Cristaria plicata (Bivalvia: Unionidae) from Lake Khanka (Fig. 1, Tables 1,2) shares a distinctive set of morphological and molecular characters and is described here as Alexandrobdella makhrovi gen. \& sp. nov. (Figs. 2, 3, 4). Our DNA analyses indicate that the crop of a paratype of Alexandrobdella makhrovi gen. \& sp. nov.[RMBH Hir_0084/1-P] was filled by blood of the Amur catfish Silurus asotus Linnaeus, 1758 (Siluridae) [GenBank accession no. MT707651].

${ }^{1}$ Northern Arctic Federal University, Arkhangelsk, Russia. ${ }^{2} \mathrm{~N}$. Laverov Federal Center for Integrated Arctic Research of the Ural Branch of the Russian Academy of Sciences, Arkhangelsk, Russia. ${ }^{\circledR}$ email: es.konopleva@gmail.com 

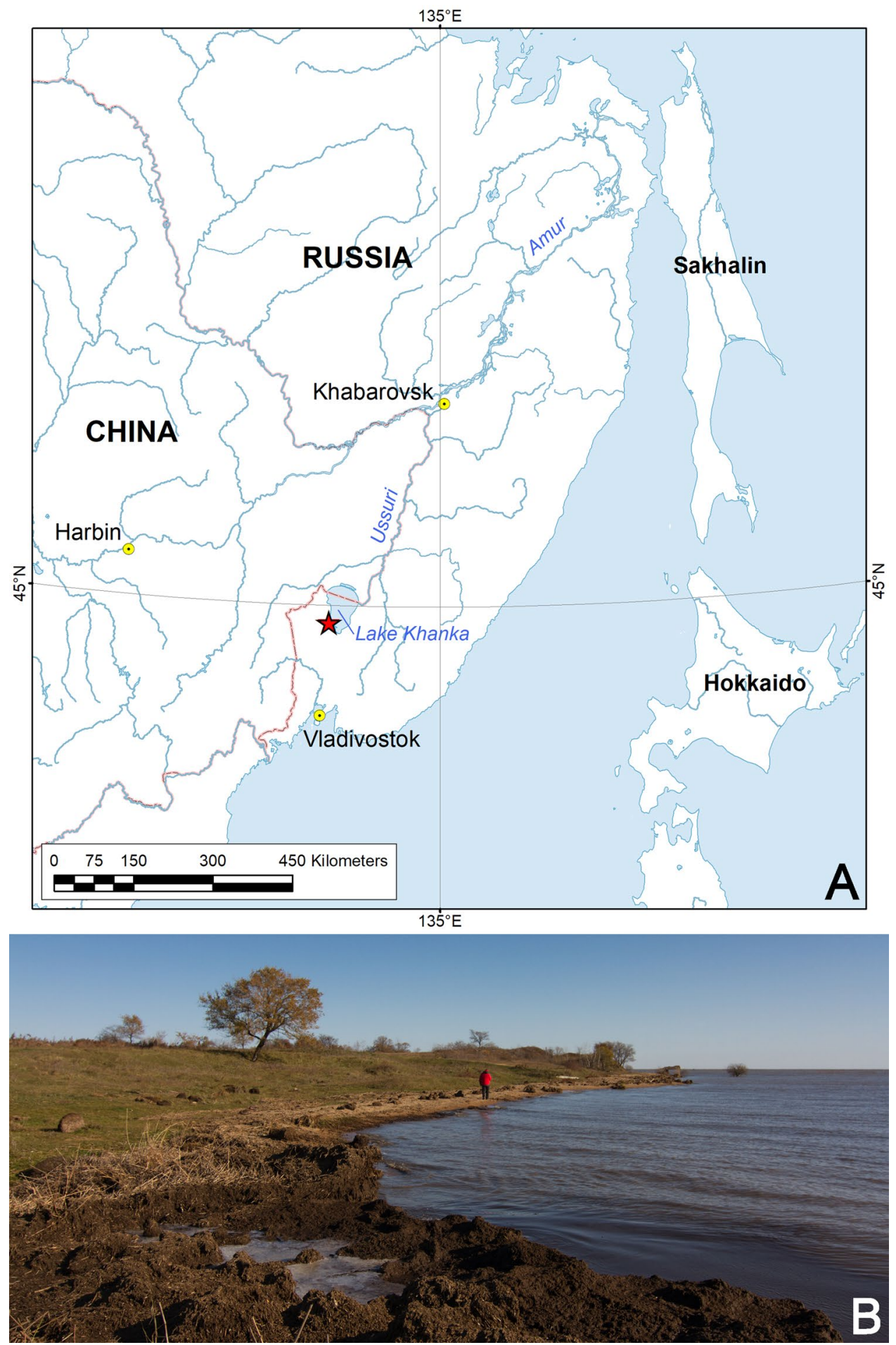

Figure 1. Type locality of Alexandrobdella makhrovi gen. \& sp. nov. (A) Geographic position of the type locality (red star). The map was created using ESRI ArcGIS 10 software (https://www.esri.com/arcgis); the topographic base of the map was created with free open sources such as Natural Earth Free Vector and Raster Map Data (https://www.naturalearthdata.com), Global Self-consistent Hierarchical High-resolution Geography, GSHHG v2.3.7 (https://www.soest.hawaii.edu/wessel/gshhg), and HydroSHEDS (https://www.hydrosheds.org). (B) Coastal area of Lake Khanka at the type locality. Photo: Ilya V. Vikhrev. 


\begin{tabular}{|c|c|c|c|c|c|c|}
\hline Genus & Species & COI & 18S rRNA & Haplotype Code & Region & Environment ${ }^{*}$ \\
\hline \multicolumn{7}{|l|}{ In-group taxa } \\
\hline \multicolumn{7}{|l|}{ Piscicolidae } \\
\hline Alexandrobdella gen. nov & A. makhrovi gen. \& sp. nov & MN295413 & MN312187 & AleMak & East Asia & Freshwater \\
\hline \multirow{2}{*}{ Limnotrachelobdella Epshtein, 1968} & L. sinensis (Blanchard, 1896) & LC275140 & LC275139 & LimSin & East Asia & Brackish to freshwater \\
\hline & L. okae (Moore, 1924) & AY336022 & N/A & LimOka & East Asia & Marine to freshwater \\
\hline Gen.1 indet & Gen. \& sp. indet. HLC-30322 & MG421319 & N/A & PisSp1 & North America & Marine \\
\hline Gen.2 indet & Gen. \& sp. indet. PT-2003 & AY336023 & N/A & PisSp2 & East Asia & Brackish to marine \\
\hline Gen.3 indet & Gen. \& sp. indet. Aio2018LYKM & LC460256 & N/A & PisSp3 & East Asia & Marine \\
\hline Caspiobdella Epshtein, 1966 & C. fadejewi (Epshtein, 1961) & AY336020 & N/A & CasFad & Europe & Brackish to freshwater \\
\hline \multirow{3}{*}{ Piscicola Blainville, 1818} & P. geometra (Linnaeus, 1761) & AY336014 & AF099946 & PisGeo & Europe & Freshwater \\
\hline & P. milneri (Verrill, 1874) & DQ414337 & DQ414292 & PisMil & North America & Freshwater \\
\hline & P. cf. annae Bielecki, 1997 & AY336016 & N/A & PisAnn & Europe & Freshwater \\
\hline \multirow{4}{*}{ Branchellion Savigny, 1822} & B. torpedinis Savigny, 1822 & AF003265 & AF115993 & BraTor & North America & Marine \\
\hline & B. lobata Moore, 1952 & DQ414307 & DQ414261 & BraLob & North America & Marine \\
\hline & B. parkeri Richardson, 1949 & DQ414308 & DQ414262 & BraPar & Australia & Marine \\
\hline & B. ravenelii (Girard, 1851) & DQ414309 & DQ414263 & BraRav & Central America & Marine \\
\hline Calliobdella van Beneden \& Hesse, 1863 & C. lophii Van Beneden \& Hesse, 1863 & DQ414314 & DQ414268 & CalLop & Europe & Marine \\
\hline Myzobdella Leidy, 1851 & M. lugubris Leidy, 1851 & AF003269 & AF115994 & MyzLug & North America & Marine to freshwater \\
\hline \multirow{3}{*}{ Pontobdella Leach, 1815} & P. macrothela (Schmarda, 1861) & AF116022 & AF115996 & PonMac & North America & Marine \\
\hline & P. tasmanica (Hickman, 1942) & DQ414343 & DQ414298 & PonTas & Australia & Marine \\
\hline & P. muricata (Linnaeus, 1758) & KY659072 & KY659070 & PonMur & Europe & Marine \\
\hline Zeylanicobdella Silva, 1963 & Z. arugamensis de Silva, 1963 & DQ414344 & DQ414299 & ZeyAru & Southeast Asia & Marine \\
\hline \multirow{2}{*}{ Aestabdella Burreson, 1976} & A. leiostomi Burreson, 1991 & DQ414305 & DQ414259 & AesLei & North America & Marine \\
\hline & A. adbitovesiculata (Moore, 1952) & DQ414300 & DQ414254 & AesAbd & Hawaii & Marine \\
\hline Cystobranchus Diesing, 1859 & C. respirans (Troschel, 1850) & AY336021 & N/A & CysRes & Europe & Freshwater \\
\hline Baicalobdella Dogiel \& Bogolepova, 1957 & B. torquata Grube, 1871 & AY336018 & N/A & BaiTor & East Asia & Freshwater \\
\hline \multirow{4}{*}{$\begin{array}{l}\text { Gonimosobdella Williams \& Burreson, } \\
2005\end{array}$} & G. klemmi Williams \& Burreson, 2005 & DQ414318 & DQ414272 & GonKle & North America & Freshwater \\
\hline & G. salmositica (Meyer, 1946) comb. nov & DQ414316 & DQ414270 & CysSal & North America & Freshwater \\
\hline & G. virginica (Hoffman, 1964) comb. nov & DQ414317 & DQ414271 & CysVir & North America & Freshwater \\
\hline & G. vivida (Verrill, 1872) comb. nov & AF003260 & AF115992 & CalViv & North America & Marine \\
\hline Bathybdella Burreson, 1981 & B. sawyeri Burreson, 1981 & DQ414311 & DQ414265 & BatSaw & East Pacific Rise & Marine \\
\hline Johanssonia Selensky, 1914 & J. artica (Johansson, 1898) & DQ414320 & DQ414274 & JohArc & North America & Marine \\
\hline \multirow{3}{*}{ Austrobdella Badham, 1916} & A. bilobata Ingram, 1957 & DQ414301 & DQ414255 & AusBil & Australia & Marine \\
\hline & A. translucens Badham, 1916 & DQ414306 & DQ414260 & AusTra & Australia & Marine \\
\hline & A. californiana Burreson, 1977 & DQ414304 & DQ414258 & AusCal & North America & Marine \\
\hline Beringobdella Caballero, 1974 & B. rectangulata (Levinsen, 1881) & DQ414310 & DQ414264 & BerRec & East Asia & Marine \\
\hline Platybdella Malm, 1863 & P. anarrhichae (Diesing, 1859) & DQ414336 & DQ414291 & PlaAna & Europe & Marine \\
\hline \multirow{2}{*}{ Heptacyclus Vasileyev, 1939} & H. scorpii (Malm, 1863) & DQ414326 & DQ414280 & MalSco & North America & Marine \\
\hline & H. buthi (Burreson \& Kalman, 2006) & DQ414322 & DQ414276 & MalBut & North America & Marine \\
\hline \multirow{2}{*}{ Oceanobdella Caballero, 1956} & O. khani Burreson \& Williams, 2004 & DQ414331 & DQ414286 & OceKha & East Asia & Marine \\
\hline & O. sexoculata $($ Malm, 1863$)$ & DQ414332 & DQ414287 & OceSex & North America & Marine \\
\hline Notostomum Levinsen, 1882 & N. cyclostomum Johansson, 1898 & DQ414327 & DQ414282 & NotCyc & East Asia & Marine \\
\hline Notobdella Benham, 1909 & N. nototheniae Benham, 1909 & DQ414330 & DQ414285 & NotNot & Antarctica & Marine \\
\hline Oxytonostoma Malm, 1863 & O. typical Malm, 1863 & DQ414333 & DQ414288 & OxyTyp & North America & Marine \\
\hline Trachelobdellina Moore, 1957 & T. glabra Moore, 1957 & EF405597 & N/A & TraGla & Antarctica & Marine \\
\hline \multicolumn{7}{|l|}{ Outgroup taxa } \\
\hline \multicolumn{7}{|l|}{ Ozobranchidae } \\
\hline \multirow{2}{*}{ Ozobranchus Quatrefages, 1852} & O. branchiatus (Menzies, 1791) & KF728213 & KF728214 & OzoBra & North America & Marine \\
\hline & O. margoi (Apáthy, 1890) & KJ451407 & KF728217 & OzoMar & North America & Marine \\
\hline
\end{tabular}

Table 1. List of COI and $18 S$ rRNA gene sequences of the Hirudinea used in this study. N/A not available. ${ }^{\star}$ Data on environmental preferences was obtained from the IRMNG database (https://www.irmng.org ${ }^{33}$ and published sources ${ }^{19,34}$. 


\begin{tabular}{|c|c|c|c|c|c|c|c|}
\hline \multirow[b]{2}{*}{ Status of specimen } & \multirow[b]{2}{*}{ Voucher no.* } & \multirow[b]{2}{*}{ COI acc. no } & \multirow[b]{2}{*}{$18 S$ rRNA acc. no } & \multicolumn{4}{|c|}{ Measurements $(\mathrm{mm})^{* *}$} \\
\hline & & & & \begin{tabular}{|l|} 
BL \\
\end{tabular} & BW & AW & PW \\
\hline Holotype & RMBH Hir_0084/2-H & N/A & N/A & 14.5 & 2.20 & 1.10 & 1.95 \\
\hline Paratype & RMBH Hir_0084/1-P & MN295413 & MN312187 & 12.6 & 3.36 & 1.03 & 1.75 \\
\hline Paratype & RMBH Hir_0086-P & N/A & N/A & 11.0 & 2.26 & 0.84 & 1.41 \\
\hline
\end{tabular}

Table 2. Voucher numbers, reference DNA sequences, and measurements of the type series of Alexandrobdella makhrovi gen. \& sp. nov. N/A not available. ${ }^{\star}$ Type series is deposited in the $R M B H$ Russian Museum of Biodiversity Hotspots, Federal Center for Integrated Arctic Research of the Ural Branch of the Russian Academy of Sciences, Arkhangelsk, Russia. ${ }^{*}$ Measurements of leech specimens (mm): $B L$ body length, $B W$ body width, $A W$ width of anterior sucker, and $P W$ width of posterior sucker.

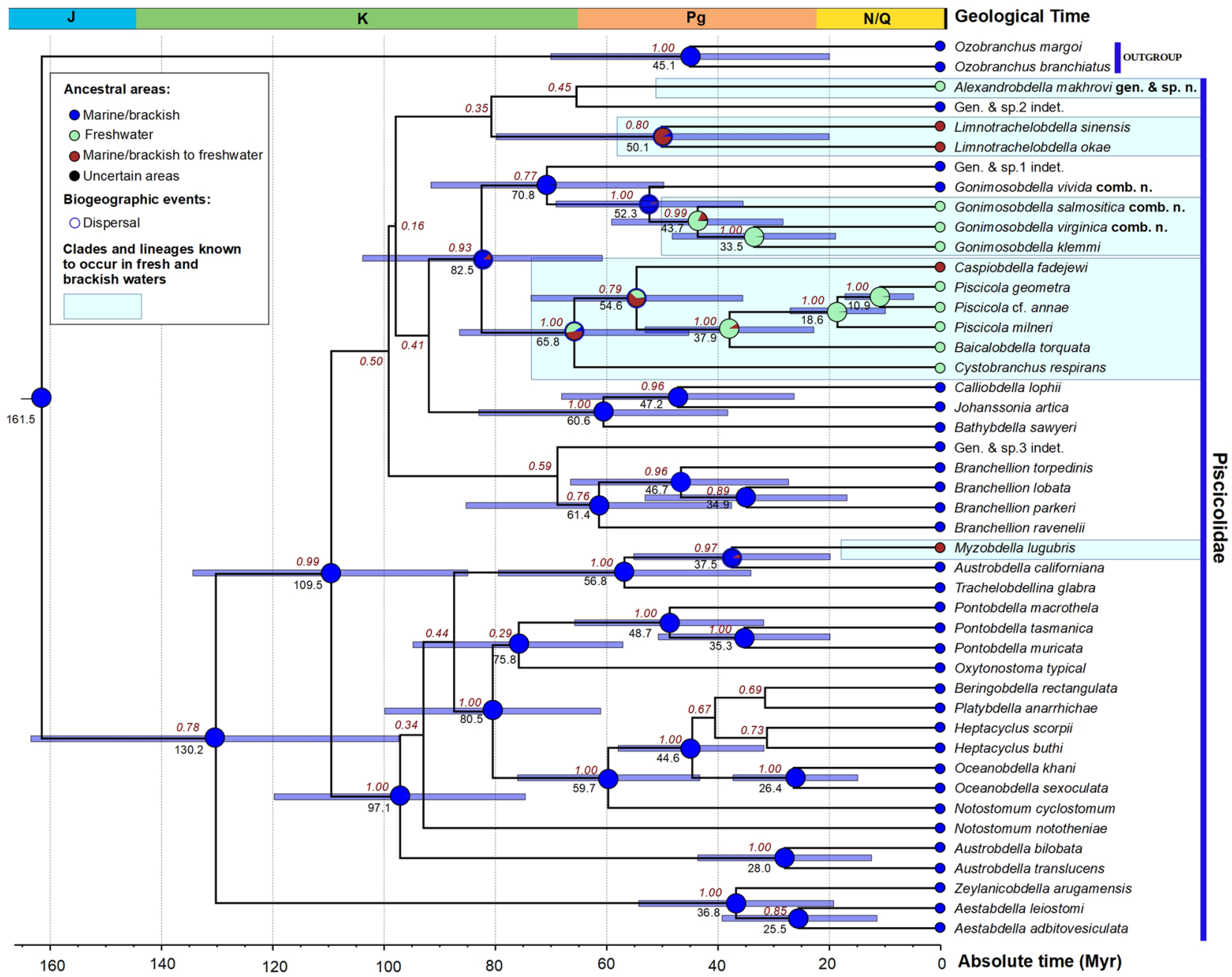

Figure 2. Bayesian time-calibrated phylogeny (four partitions: three codons of COI $+18 \mathrm{~S}$ rRNA) and ancestral environment reconstruction of the Piscicolidae. Brown numbers near nodes are BPP values of BEAST. Black numbers near nodes are node ages (Myr). The tip circles indicate environmental preference of leech species: freshwater (blue); marine (green); and euryhaline (brown) (Table 1). Reconstructions for weakly supported nodes $(\mathrm{BPP}<0.75)$ are omitted. Two Ozobranchidae taxa were used as outgroup.

Therefore, freshwater fish can be considered the primary hosts of Alexandrobdella, while the nature of its association with freshwater mussels (i.e., shelter only or a secondary host as well) remains largely unclear.

The deep subfamily-level nodes of our two-locus Bayesian phylogeny $(C O I+18 S$ rRNA) were rather weakly supported, while shallower nodes corresponding to generic and intra-generic clades shared high and moderate support values (BPP $\geq 0.95$ and $\geq 0.75$, respectively). Phylogenetically, Alexandrobdella makhrovi gen. \& sp. nov. was recovered within a weakly supported clade that contains Limnotrachelobdella spp. and an unidentified 


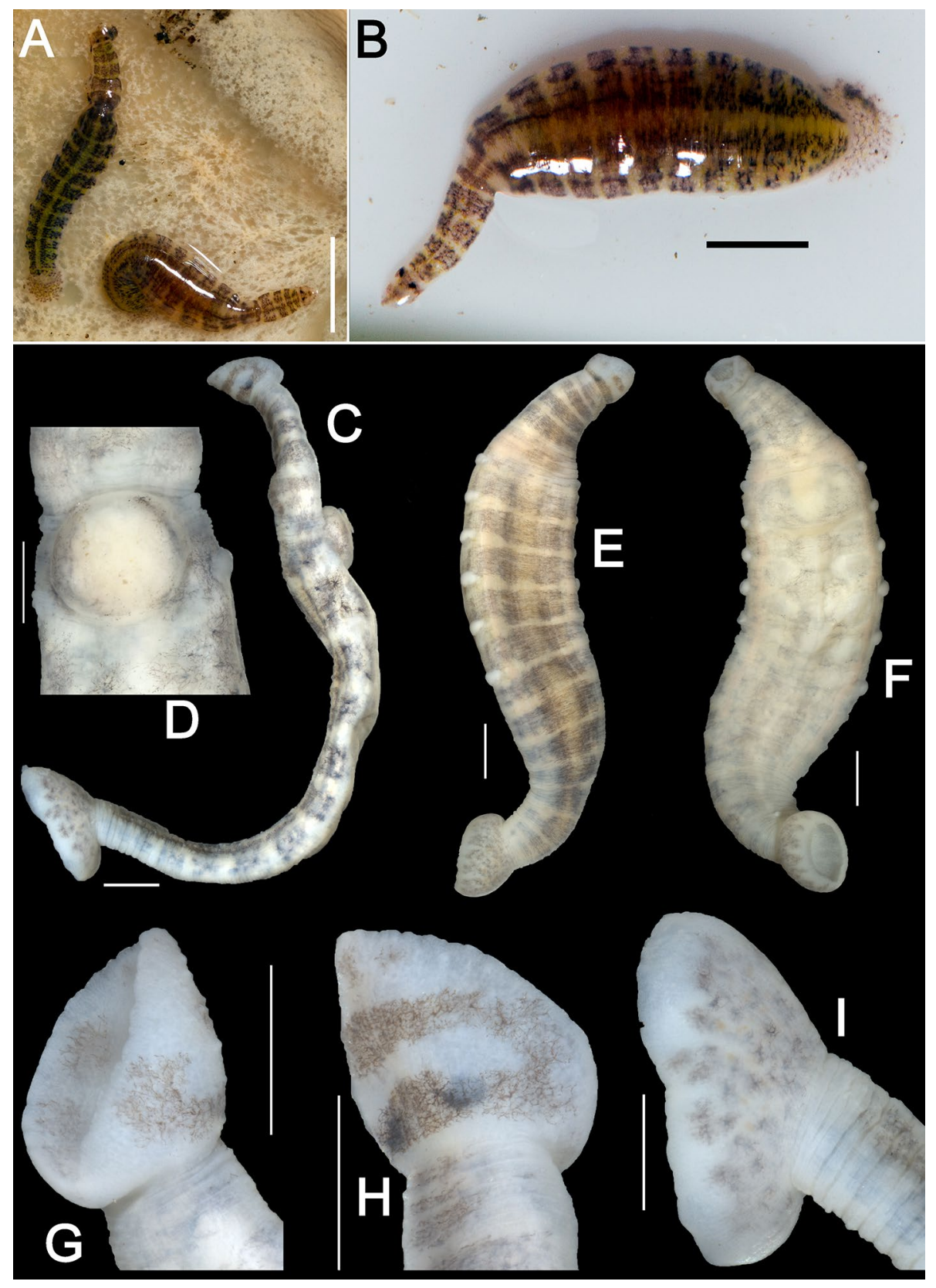

Figure 3. Morphology of the type specimens of Alexandrobdella makhrovi gen. \& sp. nov. (A) Living holotype Hir_0084/2-H and paratype RMBH Hir_0084/1-P specimens (dorsal view) in the mantle cavity of their host mussel Cristaria plicata (Bivalvia: Unionidae), 24.v.2017. (B) Living paratype Hir_0084/1-P (dorsal view), 24.v.2017. (C) Holotype Hir_0084/2-H (lateral view). (D) Clitellum of the holotype (ventral view). (E) Paratype Hir_0086-P (dorsal view). (F) Paratype Hir_0086-P (ventral view). (G) Anterior sucker of the holotype (lateral view). (H) Anterior sucker of the holotype (dorsal view). (I) Caudal sucker of the holotype (lateral view). Scale bars $=5 \mathrm{~mm}[\mathrm{~A}], 2 \mathrm{~mm}[\mathrm{~B}]$, and $1 \mathrm{~mm}$ [C-I]. Photos: Ilya V. Vikhrev [A-B] and Anna L. Klass [C-I].

marine leech species (Fig. 2). This group appears to be a part of the subfamily Piscicolinae, which was also weakly supported in our research.

Our ancestral trait modeling suggested that there were at least five independent colonization events of piscicolids to fresh and brackish water: (i) Piscicola + Baicalobdella + Cystobranchus respirans + Caspiobdella $(\mathrm{BPP}=1.00)$; (ii) Gonimosobdella klemmi + G. salmositica comb. nov. + G. virginica comb. nov. $(\mathrm{BPP}=0.99)$; (iii) Limnotrachelobdella (BPP =0.80); (iv) Myzobdella lugubris (BPP =0.97); and (v) Alexandrobdella makhrovi gen. \& sp. nov. $(\mathrm{BPP}=0.45)$ (Fig. 2$)$.

Taxonomy. Family Piscicolidae Johnston, 1865.

Genus Alexandrobdella gen. nov. 


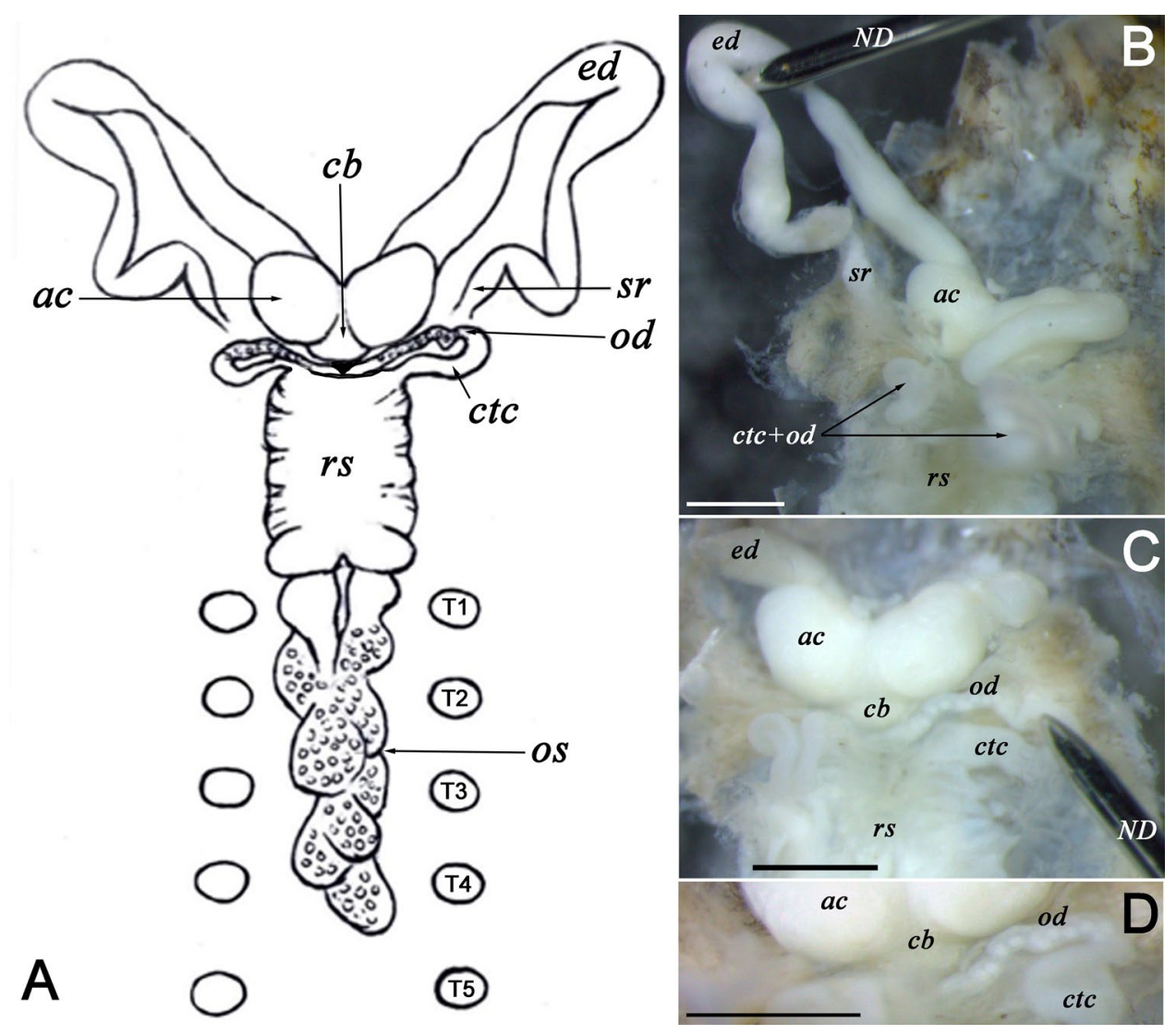

Figure 4. Reproductive system of Alexandrobdella makhrovi gen. \& sp. nov. (dorsal view). (A) General scheme of the system (graphics). (B) Left ejaculatory duct and seminal reservoir expanded. (C) Right oviduct and conductive tissue cord expanded. (D) Same characters but with higher magnification. Abbreviations: ac atrial cornu (terminal parts of the ejaculatory ducts); $c b$ copulatory bursa; $e d$ ejaculatory ducts; $s r$ seminal reservoir; ctc conductive tissue cords; $r s$ seminal receptacle; os ovisacs; od oviducts; $T$ testisac with corresponding number; and ND dissecting needle. Scale bars $=0.5 \mathrm{~mm}$. Graphics and photos: Anna L. Klass.

LSID: https://zoobank.org/urn:lsid:zoobank.org:act:E644FB76-B5F2-4405-8D13-982D362E790C.

Type species: Alexandrobdella makhrovi gen. \& sp. nov.

Etymology. This genus is named for Dr. Alexander Makhrov, a prominent Russian ichthyologist and evolutionary biologist, and "bdella", the Greek word for leech.

Diagnosis. Body flattened dorso-ventrally, clearly divided into short trachelosome and elongated urosome (Fig. 3). Both trachelosome and urosome taper towards corresponding suckers. Suckers well developed. Pulsatile vesicles present, rather large, knob-like. One pair of large eyes on oral sucker. Segmental and caudal ocelli absent. Urosomal segments 7(14) annulate. Five pairs of testisacs. Large, rectangular muscular organ (seminal receptacle) associated with bursa and ovisacs. Conductive tissue present. Conductive tissue cords conduct oviducts with the seminal receptacle (Fig. 4). Ovisacs massive, asymmetric, lobed. There are no freshwater genera of the Piscicolidae having such combination of morphological characters, although Limnotrachelobdella Epshtein, 1968 and Taimenobdella Epshtein, 1987 appear to be more closely related to the new genus externally. However, Alexandrobdella gen. nov. differs from Limnotrachelobdella Epshtein, 1968 by having smaller, knob-like pulsatile vesicles, a less distinct separation of the body into trachelosome and urosome, and a smaller posterior sucker. It can be distinguished from Taimenobdella Epshtein, 1987 by having one pair of eyes and larger pulsatile vesicles, and by the lack of segmental and caudal ocelli. Based on the reproductive system morphology (Fig. 4), the new genus can be distinguished from all the other Piscicolidae genera by having an exceptionally large seminal receptacle and massive, asymmetrical, lobed ovisacs. The Antarctic genus Trulliobdella Brinkmann, 1948 is partly similar to the new genus in that it shares oviducts connecting with the seminal receptacle by conductive tissue cords ${ }^{18}$. However, Alexandrobdella gen. nov. has a much larger, rectangular seminal receptacle and different morphology of ovisacs compared with those in Trulliobdella species.

Phylogenetic placement. It is clear that Alexandrobdella gen. nov. represents a highly divergent lineage, which is distant phylogenetically from other freshwater and marine piscicolid genera, the DNA sequences of which were available (Fig. 2 and Table 1). This genus appears to be more closely related to Limnotrachelobdella and an unidentified marine leech Gen.2 indet. but these relationships were poorly supported in our phylogeny $(\mathrm{BPP}=0.35-0.45)$.

Alexandrobdella makhrovi gen. \& sp. nov. 
Figures 1, 2, 3, 4; Table 2.

LSID: https://zoobank.org/urn:lsid:zoobank.org:act:2723D77F-9AC1-4E41-AA21-1952FD97A94B.

Common name: Alexander Makhrov Leech.

Holotype RMBH Hir_0084/2-H, RUSSIA: Lake Khanka, 44.7065² N, 132.0728 ${ }^{\circ}$, 24.v.2017, Bolotov, Makhrov, and Vikhrev leg.

Paratypes. RUSSIA: type locality, same collectors, 24.v.2017, one sequenced specimen [RMBH Hir_0084/1-P; Table 2], 25.v.2017, one specimen [RMBH Hir_0086-P].

Mussel host. The type series was collected from the mantle cavity of the freshwater mussel species Cristaria plicata (Leach, 1814) (Bivalvia: Unionidae).

Fish host. The Amur catfish Silurus asotus Linnaeus, 1758 (Siluridae) [GenBank accession no. MT707651]. The host range of this leech needs future studies as the crop content of only one leech was sequenced.

Etymology. This novel species is dedicated to our friend and colleague Dr. Alexander Makhrov as is the new genus. Alexander helped us to collect the type series from Lake Khanka.

Morphological diagnosis. External morphology: Small leech, body flattened dorso-ventrally, clearly divided into trachelosome and urosome. Body length with suckers up to $14.5 \mathrm{~mm}$, width up to $3.4 \mathrm{~mm}$ (at the widest part of the urosome) (Table 2). Skin smooth, without papillae, 11 pairs of knob-like pulsatile vesicles laterally (especially noticeable during pregnancy). Integuments weakly pigmented, light yellow in fixed specimens (translucent in living leeches) with a black and dark brown pigmentation. On dorsal side accumulations of pigment form dark brown transverse stripes, which together with unpigmented areas form a characteristic 'mosaic' pattern. Ventral side light yellow, almost unpigmented. Anterior sucker small, distinctly separated, approximately as broad as the width of trachelosome, eccentrically attached. One pair of eyes located on a brown stripe near the border with trachelosome. Posterior sucker medium sized (diameter approximately 1.5-2 times larger than that of the anterior sucker), eccentrically attached, eye-like spots absent, but yellow-orange spots present. Complete somite contains seven double rings. Anus separated from the posterior sucker by two annuli. Digestive system: Proboscis medium long, muscular. Oesophagus surrounded by fine salivary glands. The number of chambers of the crop in the sample was not determined. Posterior crop caeca fused incompletely, persist five fenestrae. Intestine with four chambers bearing lateral processes. Rectal dilatation located posteriorly to the posterior crop caeca. Reproductive system: Gonopores are separated by two annuli. Testisacs 5 pairs, relatively large, oval. Seminal reservoirs short. Ejaculatory ducts long, muscular, forming loops. Terminal parts of the ejaculatory ducts voluminous, spherical. Copulatory bursa small. Accessory glands not found. Ovisacs long, massive, consisting of some lobes, asymmetrical, located posteriorly of the voluminous seminal receptacle. Oviducts connected by conductive tissue cords with the seminal receptacle, which forms internal copulatory area. Externally, the copulatory area could appear as swelling of the ventral surface of clitellum.

Life style. At first glance, this new leech appears to be a mussel-associated species that uses the mantle cavity of a freshwater mussel as shelter. However, its relationship with freshwater mussels (i.e., shelter only or a hostparasite association) requires further research. The proportion of Cristaria plicata mussels infested by at least one leech in our sample from the type locality was $9.7 \%$, and the intensity of leech infestation there was $0.10 \pm 0.05$ leeches per mussel (mean \pm s.e.m.; $N=31$ mussels and 3 leeches).

Distribution. This species is known only from its type locality in the southwestern part of Lake Khanka, Russian Far East (Fig. 1).

\section{Discussion}

First association of a piscicolid leech with freshwater mussels. Earlier research revealed that global mussel-associated leech assemblage includes at least 12 species belonging to the family Glossiphoniidae ${ }^{2}$. Our novel discovery of a piscicolid leech in the mantle cavity of a freshwater mussel from East Asia expands our knowledge of mussel-leech associations. The DNA analyses of the crop content of an Alexandrobdella makhrovi gen. \& sp. nov. paratype indicated that the adult leech feeds on fish blood, i.e., uses the Amur catfish (and probably other freshwater fish species as well) as the primary host. However, nothing is known on the interactions between this leech and its host mussel. The mussel-associated glossiphoniids (Hemiclepsis and Batracobdelloides) use freshwater mussels as shelters and secondary hosts but adult leeches need to take one or several fish-blood meals to complete their life cycle ${ }^{2}$.

Freshwater piscicolid leeches are known to feed on fish blood almost exclusively ${ }^{9,19}$, while one species (Gonimosobdella virginica comb. nov.) was found to be a possible obligate egg feeder in nests of four fish taxa ${ }^{20}$. Conversely, the marine Piscicolidae share a much broader host range, with numerous species being associated with vertebrate and invertebrate taxa such as fishes, turtles, crustaceans, pycnogonids, and octopuses ${ }^{7,21-24}$. A brief review of the body of literature, outlined above, revealed that piscicolid leeches could use a variety of invertebrate animals as hosts, at least in marine environments. Hence, it is unclear whether Alexandrobdella feeds on its mussel host or uses it as available shelter only. Possible host-parasite relationships of the fish leech with freshwater mussels deserve further research efforts.

Taxonomic issues. A new genus and species, Alexandrobdella makhrovi gen. \& sp. nov., are introduced here for a mussel-associated fish leech from East Asia. This leech clearly differs from other members of the family by having an enormous seminal receptacle, which posteriorly connects with large, asymmetrical, lobed ovisacs. In its turn, the proximal parts of oviducts connected with the seminal receptacle by conductive tissue cords.

Based on our two-locus phylogeny, two freshwater Cystobranchus and one marine Calliobdella species from North America are transferred here to Gonimosobdella (Table 1), as it was already suggested in a dissertation ${ }^{19}$. The new combinations are proposed as follows: Gonimosobdella salmositica (Meyer, 1946) comb. nov., G. virginica (Hoffman, 1964) comb. nov., and G. vivida (Verrill, 1872) comb. nov. 
Multiple colonization events of marine fish leeches into fresh water. Our ancestral trait modeling supports the hypothesis that the Piscicolidae is primarily a marine group of leeches ${ }^{14,17}$. The crown group of this clade was likely originated in the Early Cretaceous. There were at least five independent colonization events of the marine fish leeches to fresh and brackish water environments since the Late Cretaceous. Multiple independent colonization events of piscicolids to oceanic trenches were also recorded, with subsequent morphological and ecological adaptations to extreme deep-sea environments ${ }^{8,25}$.

\section{Methods}

Data sampling and molecular analyses. Leeches were collected from the mantle cavity of living freshwater mussels Cristaria plicata (Bivalvia: Unionidae) that were found near the shore of Lake Khanka after a strong storm. Their habitat was a shallow littoral area of the lake with silty-sand bottom (Fig. 1). The mussel specimens were opened with an extractor and their mantle cavity was visually examined for leeches and other inhabitants that were sampled by forceps ${ }^{2}$. During the 2-day period (24-25.v.2017), we examined 31 specimens of Cristaria plicata, and collected three individuals of Alexandrobdella makhrovi gen. \& sp. nov. The leech infestation prevalence (\%) and intensity of leech parasitism estimates were calculated using the equations described in our previous papers ${ }^{1,2}$.

We obtained sequences of the mitochondrial cytochrome c oxidase subunit I (COI) and the nuclear small subunit of ribosomal RNA (18S $r R N A$ ) gene fragments from one specimen of the novel species (paratype RMBH Hir_0084) using the laboratory protocols and primers followed those described in our earlier work ${ }^{2}$.

Divergence time estimates and statistical biogeography. We sampled a comprehensive two-locus $(C O I+18 S$ rRNA) molecular dataset with 43 Piscicolidae species (Table 1). Additionally, sequences of two Ozobranchidae species were collected as outgroup. Each partition was aligned separately using the MUSCLE algorithm of MEGA7 ${ }^{26}$. The $18 S \mathrm{r} R \mathrm{NA}$ alignment was processed with GBlocks $\mathrm{v} 0.91 \mathrm{~b}^{27}$ using a set of available options for less stringent selection to eliminate hypervariable flanking and poorly aligned regions from the alignment (in summary, $74 \%$ of the initial alignment were excluded). The COI (665 bp) and 18S rRNA (1698 bp) alignments were joined to a combined alignment using FaBox v1. $5^{28}$. Divergence time was estimated using BEAST v1.10.4 $4^{29}$. The best-fit evolutionary model HKY + G+I was applied to each partition. To dating the phylogeny, we used an external mean molecular rate for the COI $\left(6.25 \times 10^{-9}\right.$ subst./site/year $)$ and $18 S \mathrm{rRNA}$ $\left(1.99 \times 10^{-10}\right.$ subst./site/year) genes that were obtained based on a comprehensive fossil-calibrated phylogeny of the Hirudinea ${ }^{2}$. A lognormal relaxed clock algorithm and the Yule speciation process were applied as the tree priors. Two independent runs, each with 25,000,000 generations (sampling every 5000 cycles) were performed at the San Diego Supercomputer Center (SDSC, University of California, San Diego, USA) through the CIPRES Science Gateway ${ }^{30}$. The resulting $\log$ files were checked for convergence of the MCMC chains with Tracer v1.7 ${ }^{31}$. The ESS values for all parameters were recorded $>200$. The sets of time-calibrated trees obtained from the two runs were joined through LogCombiner v1.10.4 $4^{29}$ with $10 \%$ burn-in. The maximum clade credibility tree was constructed based on 9000 binary time-calibrated trees using TreeAnnotator v1.10.4 ${ }^{29}$.

Ancestral trait modeling was calculated using Bayesian Binary MCMC algorithm implemented in RASP v3.2 $2^{32}$ based on the set of 9000 time-calibrated binary trees and the user-specified maximum clade credibility tree obtained in the previous BEAST analyses (see above). We coded three possible types of environmental preferences of leech species as follows: (a) freshwater, (b) marine, and (ab) euryhaline. The analysis was run with the following settings: 500,000 generations, sampling every 100th generation, $10 \mathrm{MCMC}$ chains with temperature $=0.1$ and $10 \%$ burn-in. Null distribution was not allowed.

Nomenclatural acts. The electronic edition of this article conforms to the requirements of the amended International Code of Zoological Nomenclature (ICZN), and hence the new names contained herein are available under that Code from the electronic edition of this article. This published work and the nomenclatural acts it contains have been registered in ZooBank (https://zoobank.org), the online registration system for the ICZN. The LSID for this publication is as follows: https://zoobank.org/urn:lsid:zoobank.org:pub:33993F3F-FFD14688-8219-3F6D91D81A05. The electronic edition of this paper was published in a journal with an ISSN, and has been archived and is available from PubMed Central.

\section{Data availability}

The type series of the new species is available in the RMBH-Russian Museum of Biodiversity Hotspots, Federal Center for Integrated Arctic Research of the Ural Branch of the Russian Academy of Sciences, Arkhangelsk, Russia. The sequences used in this study are presented in GenBank.

Received: 6 October 2020; Accepted: 3 November 2020

Published online: 16 November 2020

\section{References}

1. Bolotov, I. N. et al. Discovery and natural history of the mussel leech Batracobdella kasmiana (Oka, 1910) (Hirudinida: Glossiphoniidae) in Russia. Zootaxa 4319, 386-390. https://doi.org/10.11646/zootaxa.4319.2.1 (2017).

2. Bolotov, I. N. et al. Freshwater mussels house a diverse mussel-associated leech assemblage. Sci. Rep. 9, 1-22. https://doi. org/10.1038/s41598-019-52688-3 (2019).

3. El-Shimy, N. A. \& Davies, R. W. The life-cycle, ecology and host specificity of the freshwater leech Alboglossiphonia polypompholyx (Glossiphoniidae) in Egypt. Hydrobiologia 222, 173-178. https://doi.org/10.1007/BF00016156 (1991).

4. Klemm, D. J. L. (Annelida: Hirudinea) found in North American mollusks. Malacol. Rev. 9, 63-76 (1976).

5. Oka, A. Hirudinea from Inle Lake, S. Shan States, Burma. Rec. Indian Museum 24, 521-534 (1922). 
6. Oosthuizen, J. H., Hussein, M. A. \& El-Shimy, N. A. A new species of Alboglossiphonia (Hirudinea: Glossiphoniidae) from Egypt. Syst. Parasitol. 11, 123-128. https://doi.org/10.1007/BF00012262 (1988).

7. López-Peraza, D. J., Hernández-Rodríguez, M., Barón-Sevilla, B., Bückle-Ramírez, L. F. \& Grano-Maldonado, M. I. First record of Stibarobdella moorei (Annelida, Hirudinea, Piscicolidae) a marine leech parasitizing Octopus bimaculatus (Mollusca: Octopodidae) from the Mexican Pacific coast. Helminthologia 54, 322-329. https://doi.org/10.1515/helm-2017-0044 (2017).

8. Utevsky, S., Kovalchuk, A., Kovalchuk, N., Utevsky, A. \& Chernyshev, A. V. A new species of the genus Johanssonia Selensky, 1914 (Hirudinea: Piscicolidae) collected in the Kuril-Kamchatka Trench at the greatest depth ever recorded for fish leeches. Prog. Oceanogr. 176, 102133. https://doi.org/10.1016/j.pocean.2019.102133 (2019).

9. Meyer, M. C. A revision of the leeches (Piscicolidae) living on fresh-water fishes of North America. Trans. Am. Microsc. Soc. 59, $354-376(1940)$.

10. Epshtein, V. M., Utevsky, A. Y. \& Utevsky, S. Y. The system of fish leeches [Hirudinea: Piscicolidae]. Genus. Int. J. Invertebr. Taxon. 5, 401-409 (1994).

11. Sket, B. \& Trontelj, P. Global diversity of leeches (Hirudinea) in freshwater. Hydrobiologia 595, 129-137. https://doi.org/10.1007/ s10750-007-9010-8 (2008).

12. Lukin, E. I. The biological peculiarities of the fish leech Piscicola geometra [in Russian]. Trudy Nauchno-Issledovatel'skogo ZoologoBiologicheskogo Instituta Khar'kovskogo Gosudarstvennogo Universiteta 1, 144-161 (1936).

13. Epshtein, V. M. Acanthobdellid, turtle, and fish leeches of the World (system approach to classification and phylogeny). Abstract of the dissertation for the degree of Doctor of Biological Sciences [in Russian] (Leningrad, Zoological Institute of the USSR Academy of Science, 1984).

14. Utevsky, S. Y. \& Trontelj, P. Phylogenetic relationships of fish leeches (Hirudinea, Piscicolidae) based on mitochondrial DNA sequences and morphological data. Zool. Scr. 33, 375-385. https://doi.org/10.1111/j.0300-3256.2004.00156.x (2004).

15. Williams, J. I. \& Burreson, E. M. Phylogeny of the fish leeches (Oligochaeta, Hirudinida, Piscicolidae) based on nuclear and mitochondrial genes and morphology. Zool. Scr. 35, 627-639 (2006).

16. Utevsky, S. Y., Utevsky, A. Y., Schiaparelli, S. \& Trontelj, P. Molecular phylogeny of pontobdelline leeches and their place in the descent of fish leeches (Hirudinea, Piscicolidae). Zool. Scr. 36, 271-280. https://doi.org/10.1111/j.1463-6409.2007.00279.x (2007).

17. Tessler, M. et al. Worms that suck: phylogenetic analysis of Hirudinea solidifies the position of Acanthobdellida and necessitates the dissolution of Rhynchobdellida. Mol. Phylogenet. Evol. 127, 129-134. https://doi.org/10.1016/j.ympev.2018.05.001 (2018).

18. Utevsky, A. Y. Antarctic piscicolid leeches. Bonner zoologische Monographien 54, 1-80 (2007).

19. Williams, J. I. Monograph of the North American freshwater fish leeches (Oligochaeta: Hirudinida; Piscicolidae) and molecular phylogeny of the family Piscicolidae. Dissertations, Theses, and Masters Projects (paper 1539616905). https://doi.org/10.25773/ v5-2fh1-ex38 (Virginia, USA, 2007).

20. Light, J. E., Fiumera, A. C. \& Porter, B. A. Egg-feeding in the freshwater piscicolid leech Cystobranchus virginicus (Annelida, Hirudinea). Invertebr. Biol. 124, 50-56. https://doi.org/10.1111/j.1744-7410.2005.1241-06.x (2005).

21. Burreson, E. M. \& Allen, D. M. Morphology and biology of Mysidobdella borealis (Johansson) comb. N. (Hirudinea: Piscicolidae), from mysids in the western North Atlantic. J. Parasitol. 64, 1082-1091. https://doi.org/10.2307/3279730 (1978).

22. Meyer, M. C. \& Khan, R. A. Taxonomy, biology, and occurrence of some marine leeches in Newfoundland waters. Proc. Helminthol. Soc. Wash. 46, 254-264 (1979).

23. Utevsky, A. Y. An identification key to Antarctic fish leeches (Hirudinea, Piscicolidae). Ukr. Antarct. J. 3, 135-144 (2005).

24. Zara, F. J., Diogo Reigada, A. L., Domingues Passero, L. F. \& Toyama, M. H. Myzobdella platensis (Hirundinida: Piscicolidae) is true parasite of blue crabs (Crustacea: Portunidae). J. Parasitol. 95, 124-128. https://doi.org/10.1645/GE-1616.1 (2009).

25. Richardson, L.R. \& Meyer, M.C. Deep-sea fish leeches (Rhynchobdellae: Piscicolidae). Galathea Report: Scientific results of the Danish deep-sea expedition round the World 1950-52 12, 113-126 (1973).

26. Kumar, S., Stecher, G. \& Tamura, K. MEGA7: molecular evolutionary genetics analysis version 7.0 for bigger datasets. Mol. Biol. Evol. 33, 1870-1874. https://doi.org/10.1093/molbev/msw054 (2016).

27. Talavera, G. \& Castresana, J. Improvement of phylogenies after removing divergent and ambiguously aligned blocks from protein sequence alignments. Syst. Biol. 56, 564-577. https://doi.org/10.1080/10635150701472164 (2007).

28. Villesen, P. FaBox: an online toolbox for fasta sequences. Mol. Ecol. Notes 7, 965-968. https://doi.org/10.1111/j.1471-8286.2007.01821 .x (2007).

29. Suchard, M. A. et al. Bayesian phylogenetic and phylodynamic data integration using BEAST 1.10. Virus Evol. 4, 1-5. https://doi. org/10.1093/ve/vey016 (2018).

30. Miller, M., Pfeiffer, W. \& Schwartz, T. Creating the CIPRES Science Gateway for inference of large phylogenetic trees. in Gateway Computing Environments Workshop (GCE) 1-8 (IEEE, 2010).

31. Rambaut, A., Drummond, A. J., Xie, D., Baele, G. \& Suchard, M. A. Posterior summarisation in Bayesian phylogenetics using Tracer 1.7. Syst. Biol. 67, 901-904. https://doi.org/10.1093/sysbio/syy032 (2018).

32. Yu, Y., Harris, A. J., Blair, C. \& He, X. J. RASP (reconstruct ancestral state in phylogenies): a tool for historical biogeography. Mol. Phylogenet. Evol. 87, 46-49. https://doi.org/10.1016/j.ympev.2015.03.008 (2015).

33. Rees, T., Vandepitte, L., Decock, W. \& Vanhoorne, B. IRMNG 2006-2016: 10 years of a global taxonomic database. Biodivers. Inf. https://doi.org/10.17161/bi.v12i0.6522 (2017).

34. Burreson, E. M., Light, J. E. \& Williams, J. I. Redescription of Cystobranchus virginicus Hoffman, 1964, and Cystobranchus salmositicus (Meyer, 1946) (Hirudinida: Piscicolidae) from Freshwater Fishes in North America. Comp. Parasitol. 72, 157-165. https ://doi.org/10.1654/4161 (2005).

\section{Acknowledgements}

We are grateful to Dr. Jürgen Geist and three anonymous reviewers for their valuable comments on earlier versions of this paper. The Russian Ministry of Science and Higher Education supported the fieldworks (I.N.B., Project No. AAAA-A18-118012390161-9) and molecular analyses of the leech samples (A.V.K., project No. FSRU-2020-0007). The Russian Science Foundation funded sampling of additional free-living leech specimens throughout Northern Eurasia (I.N.B., Y.V.B., I.V.V., and A.V.K., research grant No. 19-14-00066). The Russian Foundation for Basic Research supported phylogenetic research of leeches (I.N.B., Grant No. 18-44-292001_r_ mk; and I.V.V., Grant No. 18-34-20033_mol_a_ved). The Northern Arctic Federal University supported an open access fee for this work.

\section{Author contributions}

I.N.B. developed the concept of the study. I.N.B. and I.V.V. collected samples. I.V.V. took photos of living leeches and their habitat. A.V.K. and A.L.K. designed and processed molecular analyses. A.L.K. performed morphological research and images of preserved leeches. M.Y.G. created the map. E.S.K. calculated the phylogenetic reconstructions. I.N.B., A.L.K., and E.S.K. prepared combined figures and wrote the paper, with input from Y.V.B., A.V.K., and I.V.V. All authors discussed the final version of the manuscript. 


\section{Competing interests}

The authors declare no competing interests.

\section{Additional information}

Correspondence and requests for materials should be addressed to E.S.K.

Reprints and permissions information is available at www.nature.com/reprints.

Publisher's note Springer Nature remains neutral with regard to jurisdictional claims in published maps and institutional affiliations.

(c) (1) Open Access This article is licensed under a Creative Commons Attribution 4.0 International License, which permits use, sharing, adaptation, distribution and reproduction in any medium or format, as long as you give appropriate credit to the original author(s) and the source, provide a link to the Creative Commons licence, and indicate if changes were made. The images or other third party material in this article are included in the article's Creative Commons licence, unless indicated otherwise in a credit line to the material. If material is not included in the article's Creative Commons licence and your intended use is not permitted by statutory regulation or exceeds the permitted use, you will need to obtain permission directly from the copyright holder. To view a copy of this licence, visit http://creativecommons.org/licenses/by/4.0/.

(c) The Author(s) 2020 